Signe Pihl-Thingvad*

\title{
Is self-leadership the new silver bullet of leadership? An empirical test of the relationship between self-leadership and organizational commitment ${ }^{* *}$
}

Self-leadership is theoretically assumed to be the key management approach in modern knowledge work because it strengthens the employees' commitment. This study examines the relationship between self-leadership and affective organizational commitment empirically. An underlying assumption in the self-leadership research, that employees are guided and committed by internal work ideals, is tested, and selfleadership is compared to motivational factors in traditional management theories. The results show that self-leadership positively affects organizational commitment, while the internal work ideals overall do not seem to have the expected effect. However, the effect of self-leadership on commitment disappears when the relationship is controlled for traditional motivational factors. The theoretical and practical implications of these results are discussed, and foci for future research are suggested.

Key words: self-leadership, organizational commitment, professional identity, knowledge work (JEL: D20, D23, J29, L20, L29, L30, M54)

* Signe Pihl-Thingvad, University of Southern Denmark, Department of Political Science and Public Management, Campusvej 55, DK - 5230 Odense M, Denmark.

E-mail: ssp@sam.sdu.dk

** This work was supported by the Danish Working Environment Research Fund.

Article received: 25.06 .2014

Revised version accepted after double blind review: October 20, 2014. 


\section{Introduction}

Self-leadership is crucial in knowledge work and is often articulated as the ideal management approach in modern organizations (e.g. Pearce \& Manz, 2005; DiLiello \& Houghton, 2006; Manz \& Sims, 2001). Pearce and Manz, for example, point out that self-leadership is the best solution to "fully prepare organizations for the leadership challenges of tomorrow" (Pearce \& Manz, 2005, p. 130), and they therefore present self-leadership as 'The New Silver Bullet of Leadership'. Self-leadership is identified as the primary management strategy in modern knowledge work, because self-leadership among other things is considered a very important contributor to the psychological well-being of the employees (Prussia et al., 1998; Uhl-Bien \& Graen, 1998; Houghton \& Yoho, 2005; Stewart et al., 2011). Self-leadership is especially emphasized as a necessary management strategy if the aim is to build up or strengthen the employees' commitment (Manz \& Sims, 2001, p. 23). There is a strong expectation that selfleadership and commitment are closely and positively related in the theories of selfleadership (Manz \& Sims, 2001; Pearce \& Manz, 2005; Houghton \& Neck, 2006; Bligh et al., 2006; Houghton \& Yoho, 2005). Underneath this claim lies the assumption that self-leading knowledge workers are guided by internal work ideals (Stewart et al., 2011; Manz, 1986). Highly skilled knowledge workers are supposed to develop a personal identification with the professional ideals of their work. They are guided by internal ideals and as a result prefer to work independently and develop a high level of commitment (Neck \& Houghton, 2006; Bligh et al., 2006). We find parallels to this process in classical motivation theory - If the employee experiences meaning and can fulfill higher order needs in a job, he or she will be intrinsically motivated (Maslow, 1943; Herzberg, 1966). In this way, the theory of self-leadership can be seen as a motivational theory in line with traditional motivational theories in the management literature (Konradt et al., 2009). However, despite the common agreement in the research on the advantages of self-leadership in relation to commitment, the empirical evidences of these expectations are very sparse (Andressen et al., 2012; Stewart et al., 2011).

The aim of this paper is therefore to examine the relationship between selfleadership and commitment empirically. The study contributes in three important ways to the current research on self-leadership. First, the relationship between selfleadership and organizational commitment will be empirically tested. This will fill a rather large gap in the current research, since commitment is one of the most commonly suggested outcome variables in the self-leadership theories (Stewart et al., 2011, p. 196; Neck \& Houghton, 2006, p. 283). Second, the paper will scrutinize the underlying assumption in the self-leadership research that knowledge workers are primarily committed by their internal work ideals. It is proposed that knowledge workers are likely to be committed by their professional work ideals, because professional ideals have turned out to be one of the strongest media for knowledge workers' identity construction (Alvesson, 2004; Alvesson \& Willmott, 2002). Third, self-leadership will be compared to traditional motivational factors in management theories to test if selfleadership can actually be seen as 'the new silver bullet of leadership' in modern knowledge work. 
The next section briefly reviews the literature on self-leadership with focus on the relationship between self-leadership and commitment. To compare self-leadership with incentives in traditional management approaches, a short discussion of incentives in Scientific Management, Human Relations and Human Resource Management is provided. From these theoretical discussions, three hypotheses are deduced. Hereafter, data and methods will be presented. Data was collected via a self-report survey among journalists in Denmark. Using regression analysis, the theoretical assumptions about self-leadership and commitment will be examined, and finally the theoretical and practical implications of the results are discussed.

\section{Theoretical background and hypotheses}

Based on the assumption that knowledge work is dependent on highly skilled professional employees who cannot be managed in the traditional way through standardization and control (Alvesson, 2004), a large part of the research focuses on selfleadership as the key management approach in modern knowledge work (DiLiello \& Houghton, 2006; Manz \& Neck, 2004; Alvesson \& Willmott, 2002; Manz \& Sims, 2001).

Self-leadership was, in the early discussions defined by Manz, in opposition to external organizational controls (e.g. external management or leadership) as: "a comprehensive self-influence perspective that concerns leading oneself toward performance of naturally motivating tasks as well as managing oneself to do work that must be done but is not naturally motivating." (Manz, 1986, p. 589). The concept relies on intrinsic motivation - where the employees' actions are controlled by internal rather than external incentives: "true self-leadership is based on the personal meaningfulness and 'ownership' of the individual's governing standards" (Manz, 1986, p. 589). Thus, selfleadership is dependent on the individuals' guiding working standards (Manz, 1986, p. 590), which in recent psychological research is discussed as work identity (Haslam, 2004; Haslam et al., 2011). Furthermore, self-leadership is defined by the employees' organizational discretion concerning his or her opportunity to address what is to be done, why and how the work is performed (Manz, 1986, p. 590). However, even though self-leadership provides the employees with more responsibility, autonomy and control over the work process, self-leadership still allows for external influences from the management, for example empowering actions from the leader to create intrinsic rewards (Stewart et al., 2011, p. 189; Manz \& Sims, 2001, p. 25). Stewart et al. point to the paradoxical situation that external leadership is usually a necessary component of effective self-leadership in practice (Stewart et al., 2011, p. 189). They conclude that self-leadership should not be understood as a discrete construct, but rather that "selfleadership falls along a continuum ranging from low for behavior that is externally governed to high for individuals who determine not only how to carry out tasks but also what those tasks are and why they should be done." (Stewart et al., 2011, p. 190). It is difficult to set a precise defining limit beyond which we are sure to talk of selfleadership. Therefore, Stewart et al. suggest to use a broader definition of selfleadership (than the one originally proposed by Manz), which includes "individuals and teams that are somewhere along the self-leadership continuum beyond external 
control [and with] at least some degree of internal control." (Stewart et al., 2011, p. 190).

There has also been a historical progression in the research in the priority given to different aspects of the self-leadership construct. In the early American approach, self-leadership was understood as a process of self-influencing (Manz, 1986; Manz \& Sims, 2001; Neck \& Manz, 2004), and there was a focus on the subjective psychological strategies the individual employee used to focus on and support his or her intrinsic motivation to work (e.g. positive mental representation of the work or positive selftalk) (Manz, 1993, 1986; Prussia et al., 1998; Houghton \& Neck, 2002). Thus, this part of the research primarily focusses on the behavioral and cognitive aspects of selfleadership, but is less concerned with addressing the organizational room for maneuver in relation to the employees' self-leadership for example how much autonomy and professional discretion the employee has in his daily practice. However, the organizational range of self-leadership has been emphasized in other parts of the research. Discussions of self-leadership on group level primarily address the organizational aspect of self-leadership, e.g. how much discretion the employees have in relation to what should be done, how it should be done and why (Stewart et al., 2011; Bligh et al., 2006; Shipper \& Manz, 1992). Thus, in the recent research the perspective on selfleadership has changed toward a broader and more encompassing definition, which includes both psychological and organizational aspects (Stewart et al., 2011, p. 188).

\subsection{Self-leadership and commitment}

As mentioned above, self-leadership is dependent on and connected to intrinsic motivation (Manz, 1986, p. 590; Pearce \& Manz, 2005, p. 133; Houghton \& Yoho, 2005; Neck \& Hougthon, 2006). In this way, self-leadership can be seen as the latest approach in a long line of management approaches to employees' work motivation (Konradt et al., 2009; Manz, 1986). In general, self-leadership is discussed as 'the new silver bullet of leadership' because of its positive influence on the employees' psychosocial well-being. Research has linked self-leadership to psychological empowerment (Lee \& Koh, 2001), increased self-efficacy (Prussia et al., 1998; Neck \& Manz, 1996), job satisfaction (Neck \& Manz, 1996; Uhl-Bien \& Graen, 1998), performance (Konradt et al. 2009; Hauschildt \& Konradt, 2012) and reduced stress and anxiety (Saks \& Ashforth, 1996). Lastly, a large part of the research predicts self-leadership to strengthen the employees' commitment (Neck \& Houghton, 2006; Stewart et al., 2011; Houghton \& Yoho, 2005; Houghton et al., 2003). In a dominating book in the field, Manz and Sims argue (2001, p. 26) that a key characteristic of self-leadership is that employees seem to be committed to a degree we have not previously thought possible. From early on, Manz pointed out that self-leadership provides the employees with more responsibility which enhances a sense of control and self-efficacy. The high degree of responsibility also urges the employees to follow their inner working standards (their work identity) and this will provide them with a strong feeling of purpose which increases their commitment (Manz, 1986, p. 592). Therefore, self-leadership is argued to be one of the strongest and most important predictors of commitment in modern organizations. 
Commitment is a concept that has received a lot of attention during the last decades and with a lot of different definitions in the psychological literature (e.g. see Mowday et al., 1979; Matheiu \& Zajac, 1990; Meyer \& Allen, 1991; Meyer \& Herscovitch, 2001). However, in the self-leadership literature commitment is most often defined as the employees' emotional attachment to, identification with and involvement in their organization (e.g. Neck \& Houghton, 2006; Pearce \& Manz, 2005). For example, Houghton and Yoho argue that self-leadership will result in a certain type of follower commitment (Houghton \& Yoho, 2005, p. 75) which they define as "a deeper relationship in which followers identify with and are involved in an organization to the extent that they are willing to give of themselves in the interest of the organization's well-being (Meyer \& Allen, 1991; Mowday, Steers, \& Porter, 1979).” (Houghton \& Yoho, 2005, p. 74). That is what Meyer and Allen describe as affective commitment, which is a central part of their conceptualization of organizational commitment (Meyer \& Allen, 1991, p. 64).

However, despite the strong expectation of a relation between self-leadership and affective organizational commitment in the self-leadership research, to date only one study has investigated this relation empirically (Andressen et al., 2012). Andressen et al. show that self-leadership among team-members acts as a process factor which mediates transformational leadership and motivation and thereby determine commitment (Andressen et al., 2012). But, even though their study indicates a positive relationship between self-leadership and affective commitment, the relationship could not be confirmed because they did not examine this relationship separately (Andressen et al., 2012, p. 77). Thus, the relationship has not yet received sufficient empirical support (Andressen et al., 2012; Stewart et al., 2011). Therefore, this article focuses on the relationship between self-leadership and affective organizational commitment.

\subsection{Professional work ideals as guiding standards in the self-leading knowledge work}

To go deeper into the explanation of the internal mechanisms in the relationship between self-leadership and commitment, this paper will draw on theories of work identity.

Manz stresses that, true self-leadership is found among employees who are guided by high internal (and often altruistic) standards in their work (Manz, 1986). Alvesson and Willmott more explicitly discuss that modern self-leadership discourses regard "employees as identity workers" (Alvesson \& Willmott, 2002, p. 622). Therefore, internal work standards are overall conceptualized as work identity in this paper. The work identity is expected to guide the self-leading knowledge workers' behavior and decisions in the organization (Alvesson, 2001; Haslam, 2004) and is furthermore assumed to provide employees with meaning and higher goals to reach in their work and thereby enhance their commitment (Manz, 1986; Haslam, 2004; Neck \& Houghton, 2006). Research in work identity among knowledge workers points to the importance of their professional education and the related professional ideals as one of the strongest media for their identity construction and, hence, their motivation and commitment (Alvesson, 2004; Alvesson \& Willmott, 2002). Of course, employees are able to draw on multiple embedded, overlapping and inter-related discourses in their iden- 
tity construction, but the important identity-generating questions: 'Who am I?' and 'What are we?' are very often answered with reference to the knowledge workers' professional background (Alvesson, 2004, p. 192; Alvesson \& Willmott, 2002, p. 625). Further, research has shown that the professional construction of the knowledge workers' work identity that takes place during their educational period is central in their self-identification, even many years after they have ended their education (Shapin, 2008; Becker \& Carper, 1956). Therefore, it is proposed that it is the selfleading knowledge workers' professional work identity that guides their behavior and decisions in the organization and, furthermore, strengthens their affective commitment.

\subsection{Traditional management approaches to employee motivation}

However, to discuss if self-leadership can be seen as 'the new silver bullet of leadership', it is necessary to compare self-leadership to work incentives in traditional management strategies. Based on an account of the progression in three historical management approaches, the paper will sketch out some paradigmatic differences in the understanding of motivation related to the span between extrinsic and intrinsic incentives to work combined with external and internal regulations of work - in other words, to the span between transactional and transformational management principles. This account should by no means be seen as exhaustive. Of course, other management approaches also incorporate ideas about external and internal incentives and regulation. However, the three management approaches have had considerable historical impact on thoughts of motivation in management theory and were therefore chosen to highlight some ideal-typical differences that are present to various degrees in most management approaches today.

\section{Scientific management}

Self-leadership as a management strategy is often described as diametrically opposed to the transactional management principles in Scientific Management. According to Taylor, managers needed to appeal directly to the workers' economic aspirations, based on the assumption that the only incentive the workers had to work was a good salary (Taylor, 1911, p. 95). Furthermore, Taylor argued that a large number of supervisors were needed to monitor and control each step in the workflow. Thus, Taylor argued for a high degree of both external incentives and external regulation in work (Taylor, 1911).

\section{Human relations}

The Tayloristic paradigm was challenged by the conclusions in the Hawthorne studies. From these studies derived a new development in management theory; Human Relations which focused on the importance of social and psychological conditions for productivity. Mayo pointed at the social climate among employees and management as important for motivation and commitment (Mayo, 1949, p. 40). There were still a focus on external regulation of work from foremen, but Human Relations also pointed to the importance of internal regulation in the workgroups because the workers exerted pressure on each other to follow the informal norms and standards of the workgroup. Thereby, Human Relations understands motivation and commitment as 
based on 'the human instinct of association' (Mayo, 1949, p. 40) rather than on (economic) external incentives. Furthermore, they highlight the importance of in-group regulation alongside external regulation.

Inspired by the new insights of the Hawthorne studies, Herzberg developed his famous motivation theory, which has played an enormous role in the understanding of motivation and commitment in management theories ever since (Herzberg, 1966, 1968). Herzberg defined motivation to work as a situation where the employee needs no outside stimulator but of his own accord wishes to work, and thereby is his own generator (Herzberg, 1966, p. 55). To make this possible, Herzberg points to job enrichment as the solution. Job enrichment is defined as work that allows employees to experience responsibility, growth, learning and personal development (Herzberg, 1966, p. 61). Herzberg's theory represents a shift in the understanding of motivation toward a focus on internal incentives to satisfy higher order needs. Compared to Taylor, Herzberg also redistributes some aspects of planning and coordination to the worker with his focus on job enrichment. Thereby, he introduces a decline in the external regulation but only in relation to work content.

\section{Human resource management}

At the end of the 20th century new demands of flexibility in modern organizations arose. Human Resource Management (HRM) answers to this challenge by focusing on structural changes and human resources in the organization. Peters and Waterman argued for more autonomy to the employees and a non-hierarchical organization in their famous book 'In search of excellence' (Peters \& Waterman, 1982). In general, HRM builds on a high degree of de-centralization in the organization based on selfmanaging teams. Instead of the control and command approach, the management is value-driven and focuses on defining precise visions and goals for the employees to follow. In this approach, we find an understanding of the employee as a person with both personal and professional needs. It is argued that it is the need for personal development and self-realization that commits and motivates employees in their daily work. Therefore, the management's job becomes to encourage them in their personal development through the daily work (Peters \& Waterman, 1982). Thus, like Herzberg HRM focuses on internal incentives to commit and motivate the employees, but this focus is combined with a de-centralized value-driven management strategy which emphasizes internal regulation on group level instead of external regulation.

If we understand self-leadership as an end to these paradigmatic shifts in the management literature thus far, self-leadership represents an approach in almost entirely opposition to Scientific Management, because self-leadership is based on internal regulation and internal incentives. Thus, historically we have seen a shift in the management theory from an emphasis on external toward internal incentives as the most central for the employees' commitment and motivation combined with a shift from external toward internal regulation of the employee as the most effective management approach in modern organizations. Thereby, self-leadership can be seen as the end so far in the progression from transactional to transformational management principles (Pearce \& Conger, 2003). 


\subsection{Summary and hypotheses}

To extend the research in self-leadership, this study will empirically explore the correlation between self-leadership and affective organizational commitment, which theories expect is strong and positive. In the self-leadership research it is an implicit assumption that knowledge workers will be committed by internal professional work ideals. Finally, it is argued that self-leadership is 'the new silver bullet of leadership' in the modern knowledge work, which indicates that self-leadership is the most effective management strategy to strengthen knowledge workers' commitment compared to other management approaches. To examine these theoretical assumptions, the following hypotheses are proposed:

H1: Self-leadership is positively related to knowledge workers' commitment.

H2: The professional work ideals are also positively related to knowledge workers' commitment.

H3: Self-leadership is the dominant positive predictor of knowledge workers' commitment compared to predictors in traditional management strategies.

\section{Method}

\subsection{Procedure and Sample}

There are variations in what is referred to as knowledge work in the research (Alvesson 1993, p. 1012). However, Blackler points to a trend in the literature that knowledge work is often defined by expertise, communication and knowledge creation in combination with computer-supported cooperative work systems (Blackler, 1995, p. 1030). These characteristics make several researchers argue that journalism is an essential display of modern knowledge work (Allvin et al., 2006; Sørensen et al., 2005), and for this reason journalists were chosen as the empirical case.

To make sure all journalists in the study were knowledge workers, an online questionnaire was sent to the population of Danish journalists working with editorial journalism (4076 journalists). Journalists working with editorial journalism produce news (knowledge creation) and are in general characterized by a high degree of selfleadership in their work (e.g. Deuze, 2005). The Danish Union of Journalists, which estimates that it organizes around $90-95 \%$ of all Danish journalists, ${ }^{1}$ granted access to e-mail addresses via its membership records. $54 \%$ of the population completed the questionnaire. Response drop-out analyses were carried out by examining descriptive comparisons with the rest of the Danish workforce ${ }^{2}$ and by 238 follow-up telephone interviews with journalists who had not responded. These response analyses showed no systematic bias. However, some respondents did not answer all questions in the

1 Until recently, the Danish Union of Journalists demanded that journalists employed in a managerial position resign from the union, and therefore the estimate is $90-95$ percent. More information about the sample and working conditions of Danish journalists can be found in (Pihl-Thingvad, 2010, 2012, 2014).

2 The descriptive comparisons of the data with the Danish workforce were conducted using data and measures from the Danish National Occupational Cohort Studies. 
questionnaire and, therefore, the analyses in this paper are conducted on a sub-sample which only includes respondents who answered all the relevant items to this particular paper. To ensure that the sub-sample is representative, it was compared to the population data in terms of age, gender, marital status, and if the respondents had children living at home. No significant differences between the sub-sample and the population data were found (see appendix A). Furthermore, the analyses were also conducted on the population data with a replacement of the missing values with means. These analyses supported all the main conclusions in this paper. ${ }^{3}$

\subsection{Measures}

\section{Self-leadership}

The newest research agrees that self-leadership is a construct of continuous nature, depending on the degree to which employees are allowed to exercise self-influence over the what (standards and objectives), why (values and strategic reasons for the objectives), and how (the actual performance of the work) of their work (Stewart et al., 2011, p. 190). However, this has often been ignored in the research, and while the early individual approach to self-leadership has developed scales focusing primarily on individual psychological aspects of self-leadership (behavioral and cognitive aspects, e.g. Manz, 1993; Prussia et al., 1998; Houghton \& Neck, 2002), a more organizational approach to self-leadership on the what, why and how is still needed in the research (Stewart et al., 2011, p. 192). Therefore, the measure of self-leadership is based on a question of the individuals' perception of his or her overall degree of self-leadership. This question is supplemented with questions about self-leadership in relation to executing the work (decisions on how the work should be done), self-leadership in relation to planning the work hours (decisions on how and when the work should be done), selfleadership in relation to the extent of the work (decisions on what work should be done), self-leadership in relation to important decisions about the work (decisions on why and what work should be done). To further validate this measure of self-leadership, the five aspects were discussed in relation to the journalists' perception of selfleadership in 5 preliminary qualitative case studies, to make sure all aspects were relevant to include in the questionnaire. ${ }^{4}$ The questions could be answered on a 5-point Likert scale from 'very seldom or never' (1) to 'very often or always' (5). From these questions, a new scale was derived with an internal consistency (Chronbach's alpha) of 0.813. The descriptive results in Table 2 indicate an overall high level of selfleadership among the journalists.

\section{Professional work ideals in Journalism}

The questions regarding the journalists' professional ideals were constructed for the purpose, based on a literature review of role perceptions and professionalism among journalists (Pihl-Thingvad, 2014; Weaver et al., 2007; Hannitzsch, 2007; Deuze, 2005)

3 The analyses are available from the author on request.

4 Methodological discussions of the overall research design and the qualitative analyses of the 5 case studies can be found in (Pihl-Thingvad, 2010, 2012). 
and further validated through the 5 qualitative case studies in the Danish news industry. The following ideals were derived:

Table 1: Professional ideals in the Danish news business

\begin{tabular}{llrrc}
\hline & & $n$ & $M$ & $S D$ \\
\hline Ideal a & To produce a competitive product & 2151 & 4.04 & 0.93 \\
Ideal $b$ & To set the agenda & 2158 & 4.13 & 0.87 \\
Ideal $c$ & To provide the citizens with stories of the typical Dane & 2149 & 3.78 & 1.12 \\
Ideal $d$ & To challenge existing knowledge & 2154 & 3.84 & 0.95 \\
Ideal $e$ & To function as 'the watch-dog' of democracy & 2145 & 3.71 & 1.21 \\
Ideal $f$ & To provide citizens with reliable and objective information & 2160 & 4.57 & 0.71 \\
Ideal $g$ & To draw attention to oneself in public & 2151 & 3.02 & 1.26 \\
Ideal $h$ & To provide a product of high quality & 2159 & 4.72 & 0.50 \\
Ideal $i$ & To break a news story & 2145 & 3.55 & 1.24 \\
Ideal $j$ & To have freedom and autonomy in the work & 2172 & 4.54 & 0,60 \\
\hline
\end{tabular}

As in several international studies of professionalism in news work, the results in the table above indicate that the majority of Danish journalists exhibit a fairly homogeneous and collective professional identity (Weaver et al., 2007; Deuze, 2005; Johnstone et al., 1972).

\section{Incentives to work in traditional management strategies}

Traditional management strategies focus on different ways to motivate and commit employees. As discussed above previous management approaches emphasize the importance of good salary, social climate, job enrichment and encouraging management to commit and motivate employees. The exact questions of the following measures are presented in appendix B.

- Good salary was measured as a single item that indicates the employees' own opinion of their salary.

- Social Climate was measured with QPS Nordic's social climate scale ${ }^{5}$ and supplemented with two questions about competition and flexibility in knowledge work. The measure consists of 5 items and has an internal reliability of 0.75 .

- Job enrichment was measured on a 4-item scale. Each item describes the existence of different enriching demands in an employee's current job. The internal consistency of the measure (Chronbach's alpha) was 0.75 .

- Encouraging management was measured by a 6-item scale derived from two scales in QPS Nordic concerning empowering leadership and support from the superior. The scale was tested for internal reliability and had a Chronbach's alpha of 0.89 .

5 QPS Nordic (General Nordic Questionnaire for psychological and social factors at work) (Wännerström et al., 2009). 


\section{Controls}

Previous studies have demonstrated that gender, age, marital status, children living at home, and job position are important for employee commitment (e.g., Angel \& Perry, 1981; Mathieu \& Zajac, 1990). International research in journalism has also shown that different media types can affect the journalists' comprehension of their work (Weaver et al., 2007). All these variables are included in the analyses as control variables.

\section{Affective organizational commitment}

To be able to test the assumption about the relation between self-leadership and commitment in the self-leadership theories, this study is focusing on the descriptions of commitment that are most commonly used in the literature on self-leadership; the employees' affective organizational commitment (e.g. Houghton \& Yoho, 2005). Affective organizational commitment is characterized by three factors: a strong belief in and acceptance of the organizations goals and values; a readiness to exert considerable effort on behalf of the organizations and a strong desire to remain a member of the organization" (Cook et al., 1981, p. 84). These dimensions were measured through QPS Nordic's affective organizational commitment scale originally derived from Mowday, Steers and Porter's Organizational Commitment Questionnaire (Mowday et al., 1979). This measure of organizational commitment is the most commonly used in the research, and strong evidence has been provided for the internal consistency, test-retest reliability and congruent, discriminant and predictive validity of the measure (Mowday et al., 1979; Meyer \& Allen, 1991; Wännerström et al., 2009). The internal consistency of the measure (Chronbach's alpha) was 0.75 . The results showed that the journalists in general were fairly committed ( $\mathrm{n}=341, M=3.85$ (where 1 indicates no commitment and 5 indicates a high commitment), $S D=0.89)$.

\section{Results}

Correlations among all the main measures in the study are reported in Table 2. As expected, almost all the professional ideals correlate positively. This supports the assumption that the journalistic ideals represent an overall coherent professional identity.

A multiple linear regression model in 4 steps was used to test the hypotheses on the empirical data. ${ }^{6}$ In the first step, the controls are included in the model. In the second step, the model allows us to examine the relation between self-leadership and commitment. In the third step, it becomes possible to account for the importance of the professional ideals, and in the fourth step, we can compare the effect of self-leadership on commitment with the effect from predictors in other management strategies. In Table 3 below, the standardized beta coefficients from the four steps in the regression are presented.

6 The regression model used in the analyses is based on an assumption about a linear relationship between the main variables and the outcome variables. The relations were tested and found adequately linear. All measures were analysed for outliers. The distribution of the residuals was controlled and found acceptable. There were no sign of heteroscedasticity. Beside this, it is an important premise that there are no signs of multicollinearity among the main variables in the analyses. A test for multicollinearity was conducted, but no signs of multicollinearity were found. 
Table 2: Correlations between all main measures

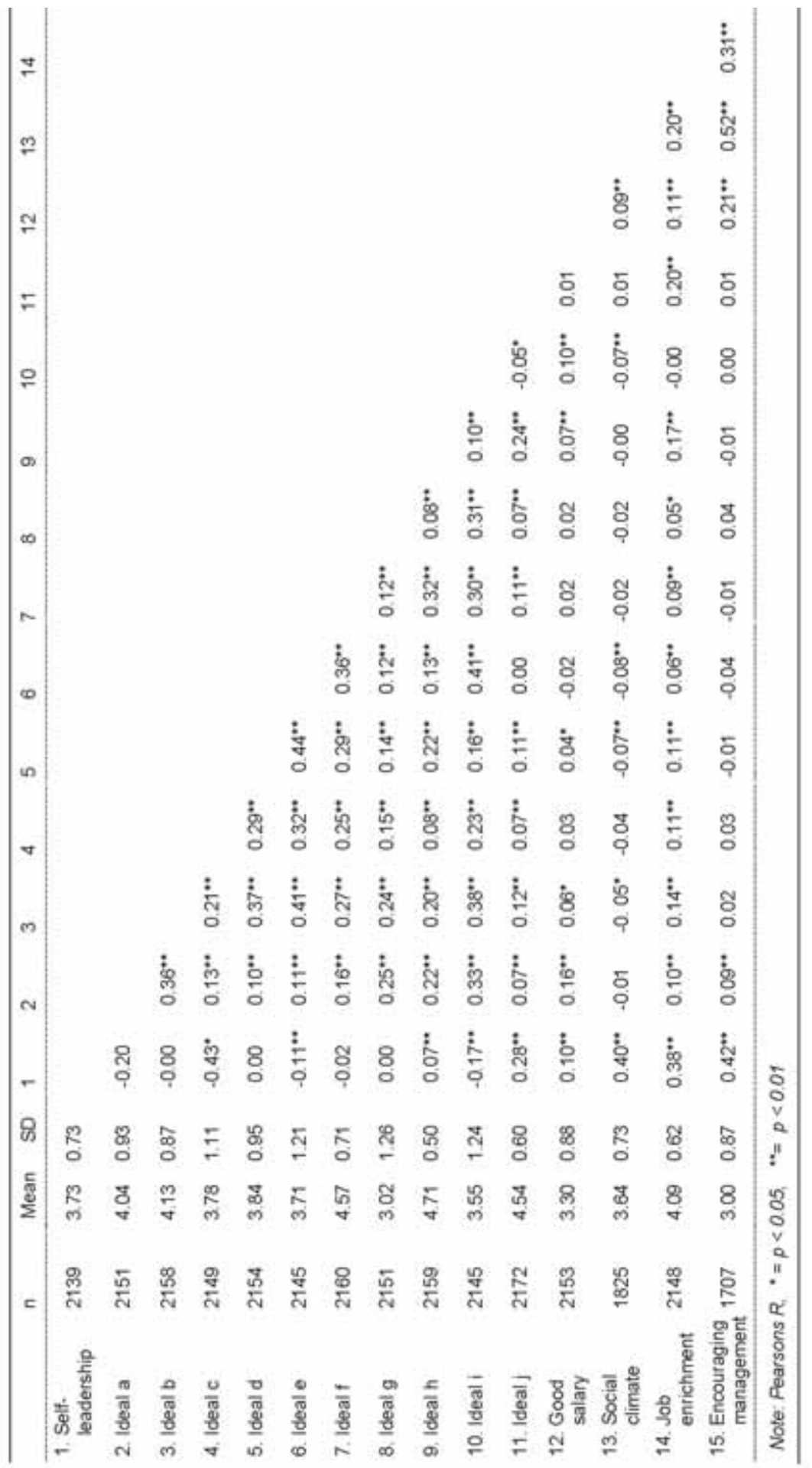


Table 3: The relationship between self-leadership and commitment

\begin{tabular}{|c|c|c|c|c|}
\hline $\begin{array}{l}\text { Affective organizational } \\
\text { commitment }\end{array}$ & Step 1 & Step 2 & Step 3 & Step 4 \\
\hline Variable & Beta & Beta & Beta & Beta \\
\hline Age & $-0.149^{*}$ & $-0.187^{* *}$ & $-0.188^{* *}$ & -0.088 \\
\hline Gender & 0.019 & 0.019 & 0.033 & 0.050 \\
\hline Children living at home & -0.113 & -0.105 & -0.079 & -0.033 \\
\hline Marital status & -0.029 & -0.017 & -0.052 & $-0.101^{*}$ \\
\hline Tv-dummya & -0.032 & 0.019 & 0.060 & 0.050 \\
\hline Radio-dummy & $-0.182^{* \star}$ & $-0.154^{* *}$ & $-0.133^{*}$ & $-0.113^{*}$ \\
\hline Other media-dummy & -0.053 & -0.064 & 0.001 & 0.026 \\
\hline Journalist-dummyb & -0.061 & 0.014 & -0.001 & -0.034 \\
\hline Photographer-dummy & -0.098 & 0.030 & 0.001 & -0.018 \\
\hline Freelancer-dummy & 0.081 & 0.101 & 0.075 & 0.049 \\
\hline Other position-dummy & 0.018 & 0.110 & 0.125 & 0.077 \\
\hline Self-leadership & & $0.442^{* *}$ & $0.393^{* *}$ & 0.075 \\
\hline Ideal a & & & $0.147^{*}$ & 0.082 \\
\hline Ideal b & & & -0.031 & -0.049 \\
\hline Ideal c & & & $0.133^{*}$ & $0.105^{*}$ \\
\hline Ideal d & & & -0.011 & 0.010 \\
\hline Ideal e & & & 0.005 & 0.001 \\
\hline Ideal $f$ & & & -0.087 & -0.054 \\
\hline Ideal g & & & $0.118^{*}$ & 0.079 \\
\hline Ideal $\mathrm{h}$ & & & -0.014 & -0.026 \\
\hline Ideal i & & & 0.122 & 0.085 \\
\hline Ideal j & & & -0.034 & 0.005 \\
\hline Good salary & & & & 0.069 \\
\hline Social climate & & & & $0.376^{\star *}$ \\
\hline Job enrichment & & & & $0.211^{* *}$ \\
\hline Encouraging management & & & & $0.119^{*}$ \\
\hline $\begin{array}{l}\mathrm{n}=263 \\
{ }^{*} p<0.05,{ }^{* *} p<0.01\end{array}$ & $\begin{array}{l}p=0.000 \\
R^{2}=0.090\end{array}$ & $\begin{array}{l}p=0.000 \\
R^{2}=0.264 \\
R^{2} \text { change }= \\
0.175^{* *}\end{array}$ & $\begin{array}{l}p=0.000 \\
\mathrm{R}^{2}=0.356 \\
\mathrm{R}^{2} \text { change }= \\
0.091^{* *}\end{array}$ & $\begin{array}{l}p=0.000 \\
R^{2}=0.531 \\
R^{2} \text { change }= \\
0.175^{\star *}\end{array}$ \\
\hline
\end{tabular}

a The reference is newspaper.

$\mathrm{b}$ The reference is manager.

The first step of the analysis examines the controls. It shows that the older the journalists are the less committed they are. Furthermore, journalists who work in the radio media are less committed than journalists who work at a newspaper. However, the 
controls do not provide a full explanation of the journalists' affective commitment, since the explained variance in the data $\left(\mathrm{R}^{2}\right)$ is only $9 \%$.

If we look at step two in the regression, the relationship between self-leadership and affective organizational commitment is tested. Hypothesis 1 assumed a positive relation between self-leadership and commitment, and as the coefficient shows $(\beta=$ $\left.0.442^{* *}\right)$ the hypothesis is supported. Thus, self-leadership has a significant positive influence on affective organizational commitment. It is important to notice, however, that the hypothesis is only supported when self-leadership is the only incentive included in the explanation.

Hypothesis 2 proposed a positive relation between the professional ideals and affective organizational commitment as well. This assumption does not seem to be strongly supported by the results in step 3. Only three of the ten ideals are significantly related to the journalists' commitment, the ideal 'to produce a competitive product', 'to provide the citizens with stories of the typical Dane' and 'to draw attention to oneself in public' are all positively related to commitment $\left(\beta=0.147^{*} ; \beta=0.133^{*}\right.$; $\left.\beta=0.118^{*}\right)$. It is worth noting, though, that two of these significant correlations disappear in the next step of the analysis, when incentives from the traditional management approaches are drawn into the analysis. Overall, hypothesis 2 was therefore not supported.

To test hypothesis 3, that self-leadership is the dominant predictor of affective organizational commitment, motivation factors from other management approaches are drawn into the analysis in step 4 . The explained variance $\left(\mathrm{R}^{2}\right)$ increases significantly from $35.6 \%$ (in step 3 ) to $53.1 \%$ (in step 4). This is quite a lot statistically and indicates that the traditional motivation factors have a substantial influence on the knowledge workers' affective organizational commitment. But contrary to what is expected in the self-leadership literature, self-leadership disappears as an important predictor when the other motivation factors enter the analysis. Only one professional ideal 'to provide the citizens with stories of the typical Dane' is significantly related to commitment. Social climate by far dominates the explanation of commitment in this model $(\beta=$ $\left.0.376^{* *}\right)$, followed by job enrichment $\left(\beta=0.211^{* *}\right)$ and encouraging management $(\beta$ $\left.=0.119^{* *}\right)$. Good salary $(\beta=0.069)$ is not significantly related to affective organizational commitment. The results suggest that not only are the traditional motivation factors more important than self-leadership in relation to affective organizational commitment, but they also steel so much explaining power from self-leadership that it becomes an insignificant predictor. Therefore, the analysis does not support that selfleadership should be the silver bullet of leadership and hypothesis 3 is rejected.

\section{Discussion and conclusion}

The study examined the relation between self-leadership and commitment. In the literature it is assumed that self-leadership positively affects employees' commitment (Manz \& Sims, 2001; Pearce \& Manz, 2005; Houghton \& Neck, 2005). Moreover, selfleading knowledge workers are supposed to orientate toward an internal work identity, which guides them in their daily work and further strengthens their commitment (Alvesson, 2004; Haslam, 2004; Alvesson \& Willmott, 2002). Therefore, many researchers argue that self-leadership is the most effective management strategy to strengthen 
the commitment of knowledge workers in modern organizations (Manz \& Sims, 2001; Pearce \& Manz, 2005; Houghton \& Neck, 2005).

The results of this study reinforce the debate on self-leadership and commitment by adding empirical evidence to the discussion. In addition, the study expands and specifies the discussion by taking the role of the employees' professional ideals into consideration. Finally, the study raises a critical question to the dominant position in which parts of the research place self-leadership concerning the best way to commit employees by comparing self-leadership to incentives in other management approaches. In this way, the study provides new information about what mechanisms strengthen the knowledge workers' commitment and what leaders can do to support these processes in modern knowledge organizations.

First, the empirical analysis showed that self-leadership does have a positive influence on knowledge workers' affective organizational commitment when it stands alone. This finding is consistent with previous research (Andressen et al., 2012). However, the impact of self-leadership on commitment disappeared, when incentives from traditional management approaches were drawn in to the analysis.

Secondly, to deepen our understanding of the relationship between selfleadership and commitment, the study focussed on the internal work standards that the self-leading knowledge workers are assumed to be guided by in their daily work (Stewart et al., 2011). Based on research in work identity among knowledge workers, it was proposed that knowledge workers should be committed by their professional work ideals in hypothesis 2 . However, this hypothesis was not supported. The results showed that the journalists did orientate toward a fairly stable collective identity, but the professional ideals representing this identity did not all correlate with commitment. However, the results call attention to further considerations. Two of the three professional ideals ('to produce a competitive product' and 'to be the one to break a news story') that were positively correlated to commitment in step 3 describe a competitive orientation toward work. This is a surprising result since the theories on selfleadership and work identity in knowledge work build their arguments on psychological theories that stress meaning in the work as the most important committing aspects contained in professional ideals (e.g. Manz \& Sims, 2001; Haslam, 2004; Alvesson, 2004; Gardner et al., 2001). This underlying way of thinking about motivation and commitment in most modern management theories derives from Herzberg's discussions of motivation (Herzberg, 1968). Herzberg first and foremost focused on individual psychological needs (as described in Maslow's pyramid of personal needs (Maslow, 1943)) and neglected other kinds of orientation in work based on rational choice principles and economic considerations. However, Herzberg has been criticized for exaggerating the importance of social and psychological factors in his interpretation of the Hawthorn studies (e.g. Rose, 1988). The results of this study show in line with this criticism that the journalists' commitment is actually influenced by their orientation toward some competitive aspects of their work. It is important that the self-leadership theories are aware that other orientations can be involved when selfleading employees are guided and committed by their professional ideals in their daily work. This seems at the very moment to be a blind spot in the comprehension of how self-leadership and internal work ideals are supposed to lead to commitment. 
Thirdly, even though the first part of the analyses showed that self-leadership was a significant predictor of affective commitment, it was only when self-leadership stands alone. When self-leadership was compared with incentives from other management approaches (Scientific Management, Human Relations and Human Resource Management), self-leadership lost its significant explanatory power. Thereby, the results from this study do not support the theoretical assumptions in the self-leadership research; that self-leadership should be the new silver bullet of leadership when it comes to affective organizational commitment. This finding is partially contradictory to the study by Andressen et al. (2012). Andressen et al. analyzed self-leadership as a process variable mediating transformational leadership, motivation and affective commitment, but they did not look at the relative role of self-leadership compared to other management approaches (Andressen et al., 2012, p. 77). This may explain the different findings. However, Andressen et al. (2012, p. 77) point to the need to clarify the role of self-leadership in relation to traditional leadership forms in their discussion. Thus, it becomes important to critically consider if self-leadership ever 'stands alone' as a predictor of commitment in modern organizations? Future research could profit from clarifying the role of self-leadership in relation to other incentives, to gain a deeper understanding of how self-leadership functions within an existing structure of incentives in the organization.

The results in this study exposed that social climate seems to play the most important role in strengthening knowledge workers affective commitment. This may be explained if we consider the nature of affective commitment. Human Relations pointed at social climate as a motivating factor, because this approach expected work motivation to derive from a feeling of being a member of a social group. Affective commitment is a dimension of organizational commitment which by definition stresses the organization as a large collective group. Becker and Billings (1993, p. 189) argue that many employees experience considerable psychological distance from the traditional global foci of organizational commitment but are relatively more attached to other foci. Therefore, it becomes important to distinguishing among foci and bases of commitment. Foci of commitment are the individuals and groups to whom an employee is attached, and bases of commitment are the motives engendering attachment (Becker \& Billings, 1993, p. 177). If we discuss self-leadership and work identity among journalists, this article has argued (following previous research) that the professional ideals are the most salient foci in the journalists' work identity and therefore also the most important foci of their commitment. But these foci are oriented toward the profession and not the organization per se, even though the organization can of course be a representative of high professional standards. Therefore, we cannot expect a strong affective organizational commitment among self-leading journalists unless the organization and the employee value the same professional standards. Furthermore, in comparison to the collective base of social climate, self-leadership stresses the individuals' need for self-actualization as the motivating driver in work. Thus, self-leading knowledge workers may be more likely to be committed by individualistic bases such as the challenges and potentials in their specific job tasks rather than by their overall organization. In this matter self-leading journalists are similar to their freelance colleagues. This is supported by the results which show no differences in the degree of affective organiza- 
tional commitment across job positions (manager, journalist, photographer, freelancer or other position). Overall, following Becker and Billings (1993), it makes good sense that social climate is the most important predictor of affective organizational commitment. The theories of self-leadership do not distinguish between different profiles of commitment, when they argue that self-leadership will strengthen the employees' affective commitment. However, the findings point to a need to revise the existing theoretical assumptions about self-leadership and commitment, because it seems that the power of self-leadership in relation to affective organizational commitment is overstated. To do this, future research should try to specify which bases and foci of commitment self-leadership is related to through both theoretical and empirical examination (Becker \& Billings, 1993; Becker, Randall, \& Riegel, 1995).

It also seems particular important for leaders in modern knowledge organizations who wish to strengthen knowledge workers' commitment to be aware of these results. Because of the current theoretical emphasis on self-leadership as the dominating predictor of commitment, there is a risk that management will overlook the importance of, for example, social climate in modern knowledge work, which would not be an advantageous management strategy according to these empirical results.

There are of course some limitations to this study that should be mentioned. First of all, the method presupposes a one-way causal direction from self-leadership to commitment, but due to the cross-sectional design used in this study, no causal direction can be empirically determined. It is also important to be aware that the casual relations describing psychosocial working factors such as self-leadership and commitment are more likely to be reciprocal over time (Konradt et al., 2009). To develop a more comprehensive understanding of the complex causal relation between selfleadership and commitment, the current conclusions could profit from research in future longitudinal studies. There are also limitations connected to the measurement of self-leadership. In this study, the measurement focuses on a specific part of the theoretical discussions, i.e., self-leadership as employees' actual control over their work and work-related decisions (the what, why and how of work). New research points to the importance of understanding self-leadership as a continuous construct related to these aspects (Stewart et al., 2011). However, this study does not address the discussions about self-leadership as different psychological techniques used by employees to control their mental processes (Manz, 1986; Manz \& Sims, 2001). Therefore, future studies could profit from combining the measure of self-leadership used in this study with measures of individual psychological techniques in analyses of the relationship between self-leadership and commitment. Finally, even though this study points to broader theoretical and practical implications, the specific results should only be directly generalized to other contexts with great caution. To expand further on our understanding of how self-leadership actually functions as a management strategy, the next step would be to compare the results from this study to similar studies in other professions.

The findings suggest three main conclusions. First, if self-leadership is considered in isolation (without being compared to incentives in other management approaches), self-leadership seems to relate positively to affective organizational commitment. But it is reasonable to ask: when would self-leadership ever be the only committing factor 
in modern organizations? It is important to evaluate self-leadership as part of an existing incentive structure in the organization and empirically try to untangle the various relationships and interactions self-leadership may have with other incentives. Second, the study elaborates on our understanding of the relationship by focusing on the importance of an internal work identity. However, the professional ideals did not turn out to have the expected effect on commitment. Only three ideals correlated positively with commitment, and two of them were based on competitive orientations. This lead suggests a critique of the assumptions about motivation and commitment in most management theories today. It is therefore important to follow this lead empirically in future research to detect what kind of ideals are essential to the work identity and how those ideals affect the process of committing self-leading knowledge workers. Third, the role of self-leadership was discussed in comparison to three ideal-typical management strategies to test if self-leadership actually is a silver bullet of leadership in modern knowledge work. The results showed that self-leadership lost its explanatory power in relation to the knowledge workers affective commitment when analysed together with traditionally known incentives to work. The findings suggest that the assumed impact of self-leadership on organizational commitment is overstated. Therefore, the relationship between self-leadership and different types of commitment needs to be further developed in the future research.

\section{References}

Alvesson, M. (1993). Organization as rhetoric: Knowledge-intensive companies and the struggle with ambiguity. Journal of Management Studies, 30, 997-1015.

Alvesson, M. (2001). Knowledge work: Ambiguity, images and identity. Human Relations, 54, 863-886.

Alvesson, M. (2004). Knowledge work and knowledge intensive firms. Oxford University Press.

Alvesson, M. \& Willmott, H. (2002). Identity regulation as organizational control: Producing the appropriate individual. Journal of Management Studies, 39, 619-644.

Allvin, M., Aronsson, G., Hagström, T., Johansson, G., \& Lundberg, U. (2006). Gränslöst arbete - socialpsykologiska perspektiv på det nya arbetslivet. LIBER, Malmö.

Andressen, P., Konradt, U., \& Neck, C.P. (2012). The relation between self-leadership and transformational leadership: Competing models and the moderating role of virtuality. Journal of Leadership \& Organizational Studies. 19, 68-82.

Becker, H., \& Carper, J. (1956). The development of identification with an occupation. The American Journal of Sociology, 61, 289-298.

Becker, T., \& Billings, R. (1993). Profiles of commitment: An empirical test. Journal of Organizational Behavior, 14, 177-190.

Becker, T., Randall, D., \& Riegel, C. (1995). The multidimensional view of commitment and the theory of reasoned action: A comparative evaluation. Journal of Management, 21, 617-638.

Blackler, F. (1995). Knowledge, knowledge work and organizations: An overview and interpretation. Organization Studies, 16, 1021-1046.

Bligh, M., Pearce, C., \& Kohles, J. (2006). The importance of self- and shared leadership in team based knowledge work - A meso-level model of leadership dynamics. Journal of Managerial Psychology, 21, 296-318

Cook, J., Hepworth, S., Wall, T., \& Warr, P. (1981). The experience of work: A compendium and review of 249 measures and their use. New York: Academic Press.

Deuze, M. (2005). What is journalism? Professional identity and ideology of journalists reconsidered. Journalism, 6, 442-464.

DiLiello, T., \& Houghton, J. (2006). Maximizing organizational leadership capacity for the future: toward a model of self-leadership, innovation and creativity. Journal of Managerial Psychology, 21, 319-337. 
Gardner, H., Csikszentmihalyi, M., \& Damon, W. (2001). Good work, when excellence and ethics meet. Basic Books.

Haslam, A. (2004). Psychology in organizations: The social identity approach. Second edition. London SAGE Publications.

Haslam, A., Reicher, S., \& Platow, M. (2011). The new psychology of leadership. Identity, influence and power. Psychology Press. Taylor \& Francis Group. Hove and New York.

Hauschildt, K., \& Konradt, U. (2012). The effect of self-leadership on work role performance in teams. Leadership, 8, 145-168.

Herzberg, F. (1966). Work and the nature of man. New York: The World Publishing Company.

Herzberg, F. (1968). One more time: How do you motivate employees? Harvard Business Review, 1968, 5362.

Houghton, J., \& Yoho, S.K. (2005). Toward a contingency model of leadership and psychological empowerment: When should self-leadership be encouraged? Journal of Leadership and Organizational Studies, 11, 65-83.

Johnstone, J., Slawski, E., \& Bowman, W. (1972). The professional values of American Newsmen. Public Opinion Quarterly, 36, 522-540.

Konradt, U., Andressen, P., \& Ellwart, T. (2009). Self-leadership in organizational teams. A multilevel analysis of moderators and mediators. European Journal of Work and Organizational Psychology 18, 322346.

Lee, M., \& Koh, J. (2001). Is empowerment really a new concept? International Journal of Human Resource Management, 12, 684-695.

Manz, C. (1986). Self-leadership: Toward an expanded theory of self-influence processes in organizations. Academy of Management Review, 11, 585-600.

Manz, C., \& Neck, C. (2004). Mastering self-leadership: Empowering yourself for personal excellence (4th ed.). Upper saddle River, NJ: Prentice Hall.

Manz, C., \& Sims, H.P. Jr. (2001). The new SuperLeadership: Leading others to lead themselves. San Francisco, Berrett-Koehler.

Maslow, A. (1943). A theory of human motivation. Psychology Review, 50, 370-396.

Matheiu, J., \& Zajac, D. (1990). A review and meta-analysis of the antecedents, correlates, and consequences of organizational commitment. Psychological Bulletin, 108, 171-194.

Mayo, E. (1949). The social problems of an industrial civilization, London: Routledge \& Kegan Paul.

Meyer, J.P., \& Allen, N.J. (1991). A three-component conceptualization of organizational commitment. Human Resource Management Review, 1, 61-98.

Mowday, R.T., Porter, L.W., \& Steers, R.M. (1979). The measurement of organizational commitment. Journal of Vocational Behavior, 14, 224-247.

Neck, C., \& Houghton, J.D. (2006). Two decades of self-leadership theory and research. Past developments, present trends and future possibilities. Journal of Managerial Psychology, 21, 270-295.

Neck, C., \& Manz, C. (1996). Thought self-leadership: The impact of mental strategies training on employee cognition, behaviour, and affect. Journal of Organizational Behaviour, 17, 445-467.

Pearce, C.L., \& Conger, J.A. (Eds.) (2003). Shared leadership: Reframing the hows and whys of leadership. Thousand Oaks, CA: Sage.

Pearce, C., \& Manz, C. (2005). The new silver bullets of leadership: The importance of self- and shared leadership in knowledge work. Organizational Dynamics, 34, 130-140.

Peters, T.J., \& Waterman, R.H. (1982). In search of excellence; lessons from America's best-run companies. Cambridge, Harper \& Row.

Pihl-Thingvad, S. (2010). Selvledelse og psykisk arbejdsmiljo i det granselose arbejde. En empirisk undersogelse af forboldet mellem selvledelse og psykisk arbejdsmiljo $i$ den danske nybedsbranche. PhD thesis. Syddansk Universitetsforlag.

Pihl-Thingvad, S. (2012). Ledelse af videnarbejdere - Selvledelse og psykisk arbejdsmiljø. Dansk Sociologi, 23, 45-77.

Pihl-Thingvad, S. (2014). Professional ideals and daily practice in journalism. Journalism. Published online first DOI 10.1177/1464884913517658. 
Prussia, G., Anderson, J., \& Manz, C. (1998). Self-leadership and performance outcomes: The mediating influence of self-efficacy. Journal of Organizational Behaviour, 19, 523-538.

Reicher, S., Haslam, A., \& Hopkins, N. (2005). Social identity and the dynamics of leadership: Leaders and followers as collaborative agents in the transformation of social reality. The Leadership Quarterly, 16, 547-568.

Roethlisberger, F.J., \& Dickson, W.J. (1939). Management and the worker: An account of a research program conducted by the Western Electric Company, Hawthorne Works, Chicago. Cambridge, MA: Harvard University Press.

Rose, M. (1988). Industrial behaviour. Research and control. London: Penguin Books.

Saks, A.M., \& Ashforth, B.E. (1996). Proactive socialization and behavioral self-management. Journal of Vocational Behavior, 48, 301-323.

Scott, W.R. (2008). Lords of the dance: Professionals as institutional agents. Organization Studies, 29, 219239.

Shipper, F., \& Manz, C. (1992). Employee self-management without formally designated teams: An alternative road to empowerment. Organizational Dynamics 20, 48-61.

Stewart, G.L., Courtright, S.H., \& Manz, C. (2011). Self-leadership: A multilevel review. Journal of Management, 37, 185-222.

Sørensen, B., Seierstad, G., \& Grinsmo, A. (2005). Tatt av ordet-Mediernes forsplill til framtidens arbeidsliv. AFI (arbeidsforskningsinstituttet). AFI rapport 4/2005.

Taylor, F.W. (1912). The principles of scientific management. Excerpts from testimony of Frederick W. Taylor at hearing before the Special Committee of the House of Representatives to Investigate the Taylor and Other Systems of Shop Management, January 25.

Uhl-Bien, M., \& Graen, G.B. (1998). Individual self-management: Analysis of professionals' selfmanaging activities in functional and cross-functional teams. Academy of Management Journal, 41, 340350.

Weaver, D., Beam, R., Brownlee, B., Voakes, P., \& Wilhoit, C. (2007). The American journalist in the 21st century. U.S. news people at the dawn of a new millennium. Lawrence Erlbaum Associates. London.

Wännerström, I., Petterson, U., Åsberg, M., Nygren, A., \& Gustavsson, P. (2009). Psychometric properties of scales in the General Nordic Questionnaire for Psychological and Social Factors at Work $\left(\mathrm{QPS}_{\text {Nordic }}\right)$ : Confirmatory factor analysis and prediction of certified long-term sickness absence. Scandinavian Journal of Psychology, 50, 231-244.

\section{Appendix A. Test of the sub-sample}

\begin{tabular}{|c|c|c|c|c|c|}
\hline & $\mathrm{N}$ & Mean & SD & $t$ & sig \\
\hline \multicolumn{6}{|l|}{ A.1. Age } \\
\hline Population data & 2174 & 45.44 & 10.27 & \multirow{2}{*}{-0.039} & \multirow{2}{*}{$0.96 s$} \\
\hline Sub-sample & 338 & 45.42 & 10.69 & & \\
\hline \multicolumn{6}{|c|}{$\begin{array}{l}\text { A.2. Gender } \\
(\text { Man }=1 \text {, Woman }=0)\end{array}$} \\
\hline Population data & 2161 & 0.5854 & 0.49277 & \multirow{2}{*}{-0.153} & \multirow{2}{*}{0.878} \\
\hline Sub-sample & 337 & 0.5816 & 0.49403 & & \\
\hline \multicolumn{6}{|c|}{$\begin{array}{l}\text { A.3. Marital Status } \\
(\text { Married/in a relationship }=1, \text { Single }=0 \text { ) }\end{array}$} \\
\hline Population data & 2173 & 0.7497 & 0.43331 & \multirow{2}{*}{1.111} & \multirow{2}{*}{0.267} \\
\hline Sub-sample & 336 & 0.7738 & 0.41899 & & \\
\hline \multicolumn{6}{|c|}{$\begin{array}{l}\text { A.4. Children living at home } \\
\left(Y_{e s}=1, N_{0}=0\right)\end{array}$} \\
\hline Population data & 2182 & 0.5165 & 0.49984 & \multirow{2}{*}{-0.602} & \multirow{2}{*}{0.547} \\
\hline Sub-sample & 339 & 0.5015 & 0.50074 & & \\
\hline
\end{tabular}




\section{Appendix B}

Self-leadership

\begin{tabular}{lccc}
\hline B.1. & $\mathrm{N}$ & $\mathrm{M}$ & $\mathrm{SD}$ \\
\hline - To which extent do you have self-leadership in your work? & 2177 & 4.06 & 0.91 \\
- If there is more than one way to do your job, do you decide how to do it yourself? & 2172 & 4.06 & 0.80 \\
- Do you have influence over the amount and extent of your work? & 2165 & 3.75 & 1.09 \\
- Do you have influence over the planning of your work time/schedule? & 2171 & 3.23 & 1.05 \\
- Are you able to influence decisions that are important for your work? & 2162 & 3.55 & 0.96 \\
\hline
\end{tabular}

All questions could be answered with; to a very high extent (5), to a high extent (4), partly (3), to a small extent (2), to a very small extent (1), or with; very often/always (5), often (4), sometimes (3), rarely (2), very rarely/never (1).

\section{Good salary}

\begin{tabular}{lccc}
\hline B.2. & $\mathrm{N}$ & $\mathrm{M}$ & $\mathrm{SD}$ \\
\hline To what degree is this condition fulfilled in your current job? - good salary & 2153 & 3.30 & 0.88 \\
\hline
\end{tabular}

All questions could be answered with; (In a very high degree (5), in a high degree (4), partly (3), in a low degree (2), not at all (1).

\section{Social Climate}

\begin{tabular}{clccc}
\hline B.3. How is the climate in the place you work? & N & M & SD \\
\hline - & Characterized by competition & 2149 & 2.99 & 1.510 \\
- & Encouraging and supportive & 1946 & 3.20 & 1.016 \\
- & Distrustful and suspicious & 2146 & 2.30 & 1.623 \\
- $\quad$ Relaxed and comfortable & 1956 & 3.38 & 1.074 \\
- $\quad$ Managed by rules and not flexible & 2143 & 2.41 & 1.609 \\
\hline
\end{tabular}

All questions could be answered with; very much (5), much (4), some (3), a little (2), very little or not at all (1). The answers to question 1,3 and 5 was reversed before entering the scale.

The social climate scale has an internal reliability of 0.75 . $(n=1825, M=3.64, S D=0.73)$.

Job enrichment

\begin{tabular}{ccccc}
\hline B.4. Demands in your work? & $\mathrm{N}$ & $\mathrm{M}$ & $\mathrm{SD}$ \\
\hline - & Is your work monotonous? & 2166 & 2.08 & 0.880 \\
- $\quad$ Does your work demand creativity and innovation of you? & 2178 & 4.18 & 0.840 \\
- $\quad$ Do you use your knowledge and competences in your work? & 2174 & 4.29 & 0.748 \\
- $\quad$ Are there positive challenges in your work? & 2181 & 3.98 & 0.805 \\
\hline
\end{tabular}

All questions could be answered with; very often or always (5), often (4), sometimes (3), seldom (2), very seldom or never (1). The answers to question 1 , was reversed before entering the scale.

The scale has an internal reliability of $0.75 .(n=2148, M=4.09, S D=0.62)$. 
Encouraging management

\begin{tabular}{|c|c|c|c|c|}
\hline B.5. & & $\mathrm{N}$ & $M$ & $S D$ \\
\hline- & Is your work appreciated by your closest superior? & 1746 & 3.34 & 1.042 \\
\hline- & $\begin{array}{l}\text { Does your closest superior encourage you to be a part of important decision } \\
\text { in your work? }\end{array}$ & 1749 & 2.92 & 1.122 \\
\hline- & $\begin{array}{l}\text { Does your closest superior encourage you to object, when you have another } \\
\text { opinion? }\end{array}$ & 1741 & 2.56 & 1.097 \\
\hline- & $\begin{array}{l}\text { Does your closest superior support you so that you can strengthen your } \\
\text { competences? }\end{array}$ & 1747 & 2.60 & 1.044 \\
\hline- & $\begin{array}{l}\text { Relaxed and comfortable Does your closest superior give a high priority to } \\
\text { the well-being in your workplace? }\end{array}$ & 1740 & 3.04 & 1.138 \\
\hline- & Is it possible to get help from your closest superior if you need it? & 1737 & 3.53 & 1.060 \\
\hline
\end{tabular}

All questions could be answered with; very often/always (5), often (4), sometimes (3), rarely (2), very rarely/never (1). The scale has an internal reliability of $0.89 . .(n=1707, M=3.00, S D=0.87)$.

\section{Controls}

\begin{tabular}{|c|c|c|c|c|}
\hline B.6. & & $\mathrm{N}$ & M & $S D$ \\
\hline- & Gender: Man (1) Woman (0) & 2174 & 47 & 10.29 \\
\hline- & Age: When were you born? (year) & 2161 & 0.5854 & 0.4928 \\
\hline- & What is your marital status? (married $=1$, Single $=0$ ) & 2173 & 0.7497 & 0.4333 \\
\hline- & Do you have children living at home? (Yes (1), No (0)) & 2182 & 0,5165 & 0.4998 \\
\hline
\end{tabular}

\section{Position}

\begin{tabular}{llrr}
\hline $\begin{array}{l}\text { B.7. What is your position in your current work? } \\
\text { Ref cat. Manager (Top executive/ managing director, Mid-level manager with responsi- } \\
\text { bility to staff, Mid-level manager with no responsibility to staff) }\end{array}$ & 2201 & N & $S D$ \\
\hline$-\quad$ Journalist (Journalist/reporter/web-journalist, Sub-editor) & 1149 & 0.5220 & 0.4996 \\
$-\quad$ Photographer/ Photo-journalist & 184 & 0.0836 & 0.2769 \\
$-\quad$ Freelancer & 313 & 0.1422 & 0.3493 \\
$-\quad$ Other position (Communication-worker, Commercial designer) & 229 & 0.1040 & 0.3054 \\
\hline
\end{tabular}

\section{Media-types}

B.8. What type of organization do you work in?

$\begin{array}{lll}\text { Ref.cat. Newspaper (National, regional and Local newspaper) } & N & M\end{array}$

2201

\begin{tabular}{|c|c|c|c|c|}
\hline- & Television (National and local television) & 486 & 0.2208 & 0.4149 \\
\hline- & Radio-station & 188 & 0.0854 & 0.2796 \\
\hline- & $\begin{array}{l}\text { Other (Internet based organization Magazine, Trade or Technical journal, } \\
\text { Own company/freelancer (working alone, Own company/freelancer (working } \\
\text { in a network), Other (open answer) }\end{array}$ & 617 & 0.2803 & 0.4493 \\
\hline
\end{tabular}

